\title{
Når den fortalte historie går op i limningen
}

\section{Om Peter Seebergs fiktive dokumentarisme}

\section{Indledning}

Fiktive fortællinger har til alle tider gjort brug af historiske begivenheder til at fremstille sammenhængende handlingsforløb, ligesåvel som historiografien har benyttet sig af fiktionaliserede fortællestrategier til at skabe mening i et ellers usammenhængende virvar af hændelser. "Hvor der ikke er nogen fortælling, er der ingen historie", citerer den amerikanske historiograf Hayden White sin italienske åndsfælle Benedetto Croce for at have sagt, og han uddyber det ved at påpege, at hvor objektivt og sagligt en moderne historiker end måtte gå til sit arbejde med res gestae, "forbliver hans fremstilling noget, der ikke er på højde med egentlig historie, hvis han mislykkes med at gengive virkeligheden i fortalt form" (White 1980, 9-10). Omend der er afgørende formelle forskelle på en fiktiv fortælling og en historisk dokumenteret genfortælling, tyder den gensidige brug, som begge fortællegenrer $g ø r$ af hinandens stof og stil, på en forbindelse mellem dem.

Formålet med den foreliggende artikel er at undersøge de måder, hvorpå forfatteren Peter Seeberg inddrog historisk materiale i sine skønlitterære tekster for at lade det undergå en forvandling, der både fører til et spil med dets mange mulige betydninger og til, at teksterne ofte underløber sig selv som et troværdigt historisk vidnesbyrd. Seeberg kaldte denne tekstgenre i sit forfatterskab for "fiktiv dokumentarisme", som er en særlig form for fiktionaliseret historie, der rummer en spændingsfyldt syntese af litterær fiktion og dokumentarisk historieskrivning. I hans tekster ender "syntesen" oftest med at skilles ad, hvorefter den fiktive fortælling tager over, og muligvis nogle gange tager overhånd, hvilket imidlertid flere steder $\mathrm{i}$ hans forfatterskab blotlægger en dybere eksistentiel problematik. Selvom Seeberg havde et grundigt kendskab til de historiske forhold, som han inddrog i sin litteratur, er det artiklens tese, at det historiske ikke i sig selv havde den store betydning i hans litterære tekster, hvilket snarere tilkommer det, der viser sig, når den fortalte historie går op i limningen og konfronterer mennesket med tiden på en kosmisk skala og med dets egen oplevede tid som endeligt væsen. 
Under inddragelse af den franske tænker Paul Ricoeurs refleksioner over forholdet mellem tid, historie og fortælling skal der her kort gøres rede for, hvordan Seeberg ind- og omarbejder historiske forhold ved at fiktionalisere dem. I en opsummering af sit vidtfavnende trebindsværk fra 1981, Tid og fortælling, sammenfatter Ricoeur den væsentligste forskel og forbindelse mellem fiktion og historie på følgende måde: I sin rekonstruktion af fortiden "gennem dokumenterne og kildekritikken holdes historikeren fast på det, som en gang er hændt" (Ricoeur 2017, 459), hvilket forfatteren af fiktion ikke i samme grad kan siges at være forpligtet på. Udforskningen af det mulige kan således give frit løb for "imaginære variationer" i et narrativt fiktionsmedium, som dog, ifølge Ricoeur, "efterligner den historiske fortælling", forsåvidt dét "at fortælle noget er at fortælle det som om det var sket" (s. 464-466). Hvad den historiografiske tilgang angår, kan den ikke sige sig helt fri fra at bruge forestillingskraftens mere eller mindre fiktionaliserede tilgang til fortiden: "det imaginæres plads er tydelig i fortidens ikke-iagttagelige karakter" (s. 465), hævder Ricoeur og angiver dermed, at udforskningen af historien åbner et fortolkningsspillerum, som kun kan udfyldes ved at gøre sig en forestilling om det, der kunne være sket midt i alt det, der rent faktisk menes at være sket.

Ricoeurs tese om historiens og fiktionens 'krydsreference' til hinanden hviler på teser og formodninger, der næppe alle lader sig underbygge. Det er ikke umiddelbart indlysende, at fiktionen altid efterligner historien ved at fortælle noget "som om det var sket". Til trods for at inddrage mulige og sågar kontrafaktiske begivenhedsforløb i sine studier vil historikeren bestræbe sig på at nå frem til det, som faktisk skete, mens fortælleren af fiktion i højere grad vil være henvist til og også ofte selv henviser til det blot mulige og forestillede i sin fortælling, dvs. det som kunne være sket. Brugeren af fiktion, det være sig forfatteren, læseren eller deltageren i et spil, befinder sig i en fortsat spænding mellem det reelle og det imaginære, hvilket ikke alene åbner for en fremstilling af det mulige på mangfoldige måder, men, som vi skal se i læsningen af Seebergs tekster, også det rent ud sagt umulige og regulært kontrafaktiske.

\section{Seebergs tidlige forfatterskab: på afstand af historien}

Seebergs debutroman Bipersonerne fra 1956 kan umiddelbart læses som et stykke fiktionaliseret historie, hvori forfatteren har indarbejdet materiale fra sit eget ophold i Berlin under anden verdenskrig. Hverken det historiske eller det selvbiografiske gives imidlertid nogen fremtrædende rolle, idet romanfortælleren i stedet koncentrerer sig om at skildre enkeltpersoners eksistentielle kriser og vanskeligheder med at opnå kontakt til det, som en af de centrale bipersoner Sim betegner "virkeligheden" (Seeberg 2018a, 114).

Enkelte gange bryder den historiske virkelighed i form af krig og ødelæggelse igennem og kommer tæt på de optrædende romanpersoner, der tolker krigens realiteter på forskellig vis. Sim ser krigen som en mulighed for at komme i centrum af begivenhedernes gang, mens en anden af bipersonerne i romanen, balteren, indfletter krigen og Tysklands plads i verdensordenen i en større fortælling om vestens forfald: 
(f Balteren havde tænkt, at tyskerne følte, at russerne ville blive det udvalgte folk [...] Det væsentlige i livet og historien, vidste tyskerne, tilhørte ikke dem mere, men folkene mod øst. I denne fornemmelse var de klart vesteuropæere. De sloges i virkeligheden for en dundrende undergang, også materielt, og for hele Europa. (2018a, 129)

Af en kladde til Bipersonerne fremgår det, at Seeberg oprindeligt knyttede denne passage i værket, som er en af de få, hvor det skildrede historiske stof gives en vidtrækkende betydning, sammen med Oswald Spenglers kritiske samtidsdiagnose i Vesterlandets undergang (Seebergs arkiv 01.01.1; se også Holst Sørensen 2003, 39-44). Med afsæt i en cyklisk naturopfattelse af historien søgte Spengler i sit storværk at forudsige den vesteuropæiske civilisations undergang og udpege dens efterfølger i en ny, opblomstrende russisk åndsform, der som forbillede havde Fjodor Dostojevskis kristne forestilling om en Jesus-skikkelses komme (Spengler 1922, 230-237, 622-623).

Seeberg ekspliciterede, at han havde ladet "noget dostojevski-russisk" indgå i en af romanens personer (Seeberg 1975, 203), hvilket kun kan være balteren, der er født i Sankt Petersborg, men som levede i Riga, inden han kom til Berlin. Han fremstilles dog ikke som nogen frelserfigur, men snarere som én, der er nået til en nøgtern erkendelse af, at der ikke findes nogen frelse for mennesket i en absurd verden, hvor "krigen er overalt" (Seeberg 2018a, 120). Er der frelse i vente for menneskene efter krigen, sådan som flere personer i romanen håber på? Det lægger Seebergs fortæller ikke op til. Romanens motto, "Høsten er forbi, Sommeren er til Ende, og vi ere ikke frelste", er hentet fra Jeremias' Bog i Det Gamle Testamente. Udover at udsætte frelsen på ubestemt tid henleder citatet opmærksomheden på årstidernes cykliske forløb, som også Spengler lagde til grund for sin historieopfattelse og brugte til at indplacere den vestlige civilisation i efterårets faldbevægelse.

Seeberg delte tydeligvis denne opfattelse af historien som cyklisk. I et interview fra 1989 udtalte han:

4 Vi må definere vores tidsbegreb på en ny måde i lighed med præhistorisk tid, hvor man så cyklisk på tingene [...] netop i mit arbejde med de ting, der er overleveret os fra tidligere tider, har jeg set, at de væsentlige kræfter i menneskers liv går igen og igen og er aldeles uhistoriske. Den menneskelige opfindsomhed gør, at vi hele tiden bearbejder det, der findes, så det opstår i nye former. Men det væsentlige indhold i menneskers liv er gentagelse. (Juhl 1989)

Bemærkelsesværdigt nok for en historisk velbevandret museumsmand som Seeberg tilkommer der ikke "de væsentlige kræfter" og "det væsentlige indhold" i menneskelivet en unik, historisk egenværdi, men de er snarere "uhistoriske" og hører til i en genkommende bevægelse. Nu bør man være varsom med at drage konklusioner angående Seebergs tidlige forfatterskab på baggrund af et interview fra slutfirserne, men som jeg vil vise, lader han i sit forfatterskab til stadighed "det uhistoriske" fremtræde igennem visse åbninger i den fortalte historie eller den historiske fortælling.

I Bipersonerne er "det uhistoriske" alene antydet i arbejdernes gentagende bevægelser og i deres udlægning af historien som et varsel om undergang eller frelse, hvilket har været den måde, hvorpå mennesker siden tidernes morgen har indrettet 
sig på tilbagevendende katastrofer og lejlighedsvise glædesstunder. Selvom Seeberg lader sin fortæller være yderst nøgtern i sin karakter- og omverdensbeskrivelse, gives der i romanen ingen detaljeret eller virkelighedsnær fremstilling af den 'store' historie. Det kan der være en dobbelt pointe med: På den ene side skildrer romanen et omfattende menneskeligt tab af virkelighedsfornemmelse og kontakt til omverdenen, hvilket gør, at romanfigurerne mest opfatter historien på afstand som noget, der undslipper dem, uden at de er med i den. På den anden side giver det Seeberg plads til at stille skarpt på de 'små' historier af levet liv, der dukker frem af historiens glemsel, når han genskaber dem i et fiktivt fortællingsmedium.

\section{Genealogi, testamente og nekrologer}

Det er først fra og med tekstsamlingen Dinosaurusens sene eftermiddag fra 1974, at Seeberg for alvor begynder at gøre brug af historisk stof, ofte med fokus på lokale ejendommeligheder, til at skabe sin egen minimalistiske prosa. Efter Bipersonerne forsvandt det historiske stort set ud af forfatterskabet. Fugls føde fra 1957 og de sytten korte fortællinger i Eftersøgningen og andre noveller fra 1962 kunne foregå på et ikke nærmere angivet tidspunkt i en hvilken som helst storby midtvejs i det tyvende århundrede. ${ }^{.}$Teksterne og de optrædende personers navne lægger op til at blive læst allegorisk og som eksperimenter med sproget, der kun i glimt viser hen til en genkendelig historisk virkelighed. I radioromanen Hyrder fra 1970 nærmede Seeberg sig en historisk forankret miljøskildring af personer, der er indfældet i en samfundsmæssig kontekst og undertiden med sansemættede årstidsangivelser; men ligesom i de foregående værker er det i højere grad filosofisk og til tider mytisk pointerede meningssammenhænge, der dominerer de fiktive handlingsforløb, som fortsat kredser om menneskers mere eller mindre abstrakte og distante forhold til den omgivende verden.

Seeberg fremholdt sin tekst "Nekrolog I (Bergske Blade)" fra Dinosaurusens sene eftermiddag som den første i genren "fiktiv dokumentarisme" (Åkerlund 1980, 16). Det dokumentariske fremgår dels af den anførte udgiver, Bergske Blade, dels af nekrologformen, der så nøgternt og koncist, som den højtidelige anledning byder, giver en kort sammenfatning af et menneskeliv. Til at indkredse denne seebergske teksttype har Bjarne Sandstrøm lånt termen "readymade" fra den franske installationskunstner Marcel Duchamp, som foregav at tage en genstand ud af en dagligdagssammenhæng for efterfølgende at indplacere den i "kunstinstitutionens præsentationsmedium": "Flytningen skaber en ny synsvinkel, som først fremmedgør og dernæst synliggør objektet: det berøves sin funktion for til gengæld at fremstå som form" (Sandstrøm 1999, 51).

Omend Sandstrøm forsigtigt siger, at genrebetegnelsen readymade mere er ment som en retningsangivelse end en præcis form- og indholdsbestemmelse, er det spørgsmålet, om den ikke ender med at anvise en retning, der kun delvist fører hen til Seebergs tekster. Seeberg selv og andre af hans fortolkere har ganske vist også gjort brug af betegnelsen (Fabian Lund 1998; Juhl 1999, 206; Skyum-Nielsen 2017, 219; Klitgård Povlsen 2017, 249), og det kan til en begyndelse virke overbevisende at anskue Seebergs brug af hverdagskendte tekstgenrer, såsom nekrologer, 
testamenter, gravindskrifter og genealogier, som fremstillinger af readymades i forlængelse af en eksperimenterende modernistisk tradition med Duchamp i spidsen.

I Seebergs genskabelse af disse hverdagskendte teksttyper stilles de imidlertid ikke blot frem til beskuelse, men de genererer fortsat betydninger, der minder om deres egen fiktive karakter. I den forstand adskiller en tekst, der opdigter et fiktivt univers, sig på afgørende vis fra et hverdagsobjekt. Duchamps berømte sneskovl eller tissekumme er blevet rykket bort fra deres oprindelige brugssammenhæng, men ingen af dem gør noget forsøg på at omarbejde eller udfordre den. En af hovedpointerne med Duchamps 'kunstværk' er at fremmedgøre et givet, ubearbejdet objekt, men ikke at 'dobbeltfremmedgøre' det, hvilket er Seebergs intention med sin fiktive dokumentarisme.

Dette er Sandstrøm også inde på, men når han hævder, at i de seebergske readymades fremtræder "den historiske virkelighed [...] så at sige uformidlet", så tabes "dobbeltfremmedgørelsen" af syne, og forfatteren gengives, som om han havde "fundet" teksterne uden at have "skrevet" dem (Sandstrøm 1999, 57). Denne historietro tilgang vidner ikke alene om en stærk undervurdering af Seebergs kreative og til tider drilske forhold til sin egen dokumentarisme, men den forbigår også, at det er i formuleringen af indholdet, at Seeberg ser en mulighed for at bearbejde og "dobbeltfremmedgøre" sine tekster, så de ikke bliver til ren form. ${ }^{2}$ På indholdsplanet bliver de ved med at udfordre læseren og modløbe sig selv som dokumentariske tekster, hvorfor vi bør fastholde betegnelsen "fiktiv dokumentarisme", , der lader sig efterspore både i hans kortprosastykker og noveller.

Vender vi tilbage til de omtalte nekrologer, rammer de en tone, som man vil kunne genfinde i de samme Bergske Blade, der anføres som udgiver. Ved at dokumentere kilden til sin tekst sporer Seeberg læseren ind på en bestemt historisk sammenhæng, som han dog samtidig sætter sit umiskendelige præg på ved at fiktionalisere. I nekrologerne om viceskoleinspektør Hans Emil Hansen og husmand Laust Hansen gives begge mere end sædvanlig god plads til at ytre sig bag Seebergs karakteristiske brug af indirekte og dækket tale, der normalt ikke ville optræde ad flere omgange i en nekrolog. De to Hansen'er får begge lejlighed til at anvende et seebergsk udtryk for en frisindet form for åbenhed: "Hvorfor ikke, sagde han altid, når nogle ytrede betænkeligheder" (Seeberg 2017a, 12), hedder det om den første Hansen. Den anden Hansen gør brug af et lignende retorisk spørgsmål i forhold til sin egen generøsitet: "hvorfor jeg har gjort så meget for andre, hvorfor skulle jeg ikke det?" (s.15). Virkningen af disse udtalelser er, at de to mænd i deres eftermæle fortsat træder levende frem for læseren, hvilket næppe er utilsigtet fra Seebergs side. I flere af sine kortprosatekster opretter Seeberg et spil mellem liv og død, hvor de døde fremstår levende.

Som et yderligere tillæg til Seebergs fiktionalisering af sin dokumentarisme skal hans inddragelse af egne inspirationskilder fremhæves. Han omarbejder historien i sin genbrug af den og skriver andre betydninger samt en anden ordlyd frem, der dog fortsat lader noget af en historisk kontekst tone igennem: Laust Hansen, der talte stærkt for at føre et uafhængigt husmandsliv på redelige vilkår uden at give køb på sin hjælpsomhed over for andre, sagde i lighed med den amerikanske digter og skribent Ralph Waldo Emerson, som Seeberg vides at have læst, at kun den, der 
står alene, kan være en kvalificeret støtte i samfundet til at hjælpe andre (Emerson 1854, 27). Den historiske sammenhæng for Emersons udtalelser var udstedelsen af en lov om, at slaver på flugt skulle føres tilbage til deres ejere, hvilket Emerson stærkt modsatte sig og opfordrede alle husmænd til at bryde med. Den danske husmand Hansen udtrykte sig på en lidt mindre moralsk og lidt mere munter måde end sin amerikanske åndsfælle: "Den der står alene, kan ikke besejres, sagde han. Den der går alene, har kun sig selv at stole på. Hans kamp for andre, var kampen for frie mennesker" (Seeberg 2017a, 15).

I sådanne korte påstande kommer selvindlysende sandheder frem, der fungerer som muntre indslag midt i den ellers alvorlige anledning. Læseren kan næsten glemme, at det er en nekrolog, der er tale om, og bliver måske ligefrem underholdt af de spøjse og underfundige ting, som de nu afdøde har sagt og gjort. Seeberg benytter sig nok af en kendt genre og søger tillige at ramme en tone i nekrologerne, der ligner den, som man eksempelvis tidligere kunne støde på i de Bergske Blade, men samtidig brydes denne tone af de mere eller mindre åbenlyse, fiktive elementer, som han lader indgå i nekrologerne i form af indirekte tale og enkelte intertekstuelle referencer, der undervejs er med til at udviske det nekrologagtige ved teksterne, uden at det dog helt forsvinder.

Der er således ikke tale om, at Seeberg stiller allerede skabte objekter ubearbejdet frem for sin læser. Hans fremstillinger er tværtimod stærkt bearbejdede redocumakes, der umiddelbart ser ud til at gengive en historisk livssammenhæng, men som er genskabt og lagt til rette i et litterært fiktionsmedium, som Seeberg til tider lader pege på sin egen karakter af fiktion. I "Nekrologer I (Bergske Blade)" er denne form for tekstuel selvreference eller metafiktion ikke umiddelbart tydelig. Den bliver tydeligere i den næstfølgende tekst i Dinosaurusens sene eftermiddag, "Genealogi (mandslinje)", der er opbygget på samme systematiske og tilsyneladende troværdige måde som en stamtavle. Om han har gjort brug af historiske personers navne hele vejen igennem, lader sig næppe verificere. Enkelte navne er velkendte fra andre familier i historien, eksempelvis Johan Tott, som var en slægtning i den berømte, svenske Vasa-kongefamilie. Han levede dog mindst et århundrede tidligere end sin navnefælle i Seebergs genealogi, hvilket skærper læserens opmærksomhed om det skabte og fiktive ved hans tekst. Seeberg har muligvis moret sig med at indsætte en historisk navnkundig person som Johan Tott i en anden familie og til en anden tid, sådan som han gør det med andre personer både i sit tidligere og senere forfatterskab. ${ }^{4}$

Hans genealogi fremstår som et fiktionaliseret historisk vidnesbyrd, der i lighed med andre genealogier knytter forbindelser mellem personer, i denne sammenhæng primært mellem mandlige familiemedlemmer, hvilket gør det muligt at aflæse og antydningsvist sige noget om den tid, hvori de levede. I Seebergs 'genskrivning' af historien bliver Johan Totts søn, Christen Glavind, som var skomager i Mariager ligesom sin fader og farfader, formodentlig opkaldt efter sin morfader, der havde samme navn. Det er velkendt, at familiemedlemmer tidligere i Danmark ofte fik navn efter deres nære slægtninge eller stedet, hvor de boede. Det sidste er tilfældet for et senere og mere omrejsende medlem af slægten, Søren Christensen Hvidsten, der ligesom sin fader og farfader var fra Hvidsteen, som bliver hans andet 
efternavn, dog kun med ét 'e' (s. 20). Dermed får Seeberg føjet en lille sproglig forandring over tid med ind i sin genealogi, samtidig med at han lader den afsløre den tiltagende sociale mobilitet, der finder sted fra Tott-anernes tætte tilhørsforhold til Mariager og skomagerlæsten - hvem skulle ellers blive ved sin læst? - til de senere omkringflyttende Hvidsten-familier.

Hvis læseren skulle begynde at tro, at her har Seeberg virkelig anstrengt sig for at gengive historiske forhold så prunkløst dokumentarisk som muligt, så vil det næstsidste navn på listen drille og udfordre denne historietro: Ud for Niels Viuf står der kun ét årstal anført: o. 1533, hvilket må være en omtrentlig angivelse af det tidspunkt, hvor han formodes at have levet. Han kan hverken være født eller død det år, hvis man skal tro, at han “deltog i Grevens Fejde” (Seeberg 2017a, 23), der fandt sted mellem 1534 og 1536; men hvis han virkelig deltog i den så berømte fejde, så kunne genealogen med hjemmel i historien og uden at risikere noget have forlænget hans liv med et år eller to ind i fremtiden. Det har Seeberg valgt ikke at gøre, hvilket kun kan få læseren til at spørge til og reflektere over forholdet mellem historie og fiktion i teksten.

Hvad Seeberg får blotlagt i genealogi-teksten, uagtet dens fiktionalitet, er det tilbagevendende moment af gentagelse, som for ham er en grundkraft i historien. Det bliver endnu tydeligere i den efterfølgende myte, "Dynasti", som ikke har forlæg i historiske forhold, men som frit fortæller en historie fra 'de varme lande' om regenters magtovertagelse og fald fra tronen. Den åbenlyst fiktive historie udgrænser ethvert forsøg på at dokumentere det skete historisk. Seeberg bevæger sig fra en overdokumenteret teksttype, genealogien, til den overnarrativiserede teksttype, myten, hvis fortæller fabulerende brygger løs på en god historie. Denne bevægelse er karakteristisk for den litterære form for dokumentarisme, som Seeberg gør brug af, og som med den svenske litterat Beate Agrells ord,

genbruger dokumentarisk materiale som verbale ready-mades for at stille spørgsmålstegn ved politiske, filosofiske og litterære emner - inklusiv selve den fortløbende fortællingsproces og selve dokumentets naturlige karakter. Litterær dokumentarisme tenderer således imod metafiktion: Enten igennem strategier, der benytter sig af "overnarrativisering" og åbenbar fabulering, eller igennem strategier, som bruger "overdokumentation", fortællemæssig reduktion og fragmentering. (Agrell 1997, 42)

Inden vi forlader Dinosaurusens sene eftermiddag, skal det første kortprosastykke i tekstsamlingen inddrages som et eksempel på Seebergs kombinerede brug af dokumentarisme og fiktionalisering: "Testamente for dyrepasser ved Ålborg Zoologiske Have Eyvind Poulsen" udgør, som det fremgår af titlen, endnu en offentlig kendt tekstgenre. Seeberg bringer den igen i anvendelse seksten år senere i Rejsen til Ribe, der ligeledes indledes med et testamente, hvilket angiver en vis kontinuitet i forfatterskabet. Det første testamentes relevans i denne sammenhæng består $i$, at det skaber en fiktion om at være et historisk dokument ved nøje at anføre den testamenterendes navn samt sted og dato for affattelsen af det. Skabelsen af fiktionen skinner tydeligt igennem i den muntre og mundtlige sprogtone, som afslører, at dyrepasseren hverken tager sig selv eller sin forestående død særligt alvorligt. Den 
lange, indledende sætning i testamentet taler sit eget tydelige sprog: "Min personlige tigerhun, Maja, som har sådan et dybt blik, og som jeg personligt har købt, fordi haven kun havde hantigre, fordi den forrige hun var død, skænker jeg til haven som en tak for mange glade dage mellem tremmerne" (s. 7).

Med det sidste, løjerlige udtryk placerer han sig selv halvt inden for burenes tremmevægge på lige fod med dyrene, som han åbenbart har et særligt forhold til, hvilket han understreger med sin brug af ordet "personlig" to gange på de to første linjer. Ordet "tigerhun", fremfor det mere ordrette "huntiger", samt navnet "Maja" understreger yderligere det personlige og særlige forhold, som han har til tigeren. De to begrundende sætninger indledt med "fordi" tilfører testamentet et mundtligt præg, som sædvanligvis ikke ville at være finde i et juridisk dokument af denne karakter. Hvis en læser skulle støde på et lignende testamente som dyrepasserens i virkeligheden, så ville han eller hun uden tvivl hæfte sig ved dets litterære præg og muligvis tænke, at det umiddelbart sprænger rammerne for, hvordan testamenter historisk set er blevet redigeret. Og dog skal man muligvis ikke helt afvise at kunne finde et testamente, der ligner den opdigtede dyrepassers, hvilket om muligt ville have passet Seeberg godt, da det holder den mulighed åben, at det fiktive stof nærmer sig og lader sig sammenligne med historisk overleveret materiale.

Seeberg udtalte på et tidspunkt en vis skepsis over for den form for biografisk litteratur, der hviler på "en rekonstruktion af en hukommelse, som ikke kan vide sig sikker" (Riisager 1999, 10:00-10:05). Hans skepsis hænger uden tvivl sammen med den usikkerhed på sin egen hukommelse, som han samme sted giver udtryk for og i sin litteratur kompenserer for med "den præciserende fantasi", der i lighed med den fiktive dokumentarisme giver indtryk af at kombinere en historisk fremstillingsform med en æstetisk forestillingsevne. Med til enhver rekonstruktion af hukommelsen eller historien hører en udlægningspraksis, som trækker på narrative og fiktive elementer, hvilket ikke forhindrer forfatteren i at gå historiske forhold efter i sømmene: “Jeg har ikke meget tilovers for dem, der skildrer en dag i 1517 uden at gøre sig den anstrengelse at undersøge hvilket vejr det var. For vi lever også med tidspunktets vejr, så det må vi have med" (Fabian Lund 1998, 14).

På den måde skriver Seeberg fiktiv dokumentarisme på baggrund af et historisk materiale, som han ofte har et førstehåndskendskab til. Et eksempel på dette fra Dinosaurusens sene eftermiddag er "Liste over de afdøde på kirkegården i Roussillon (Vaucluse, Frankrig)", et sted, hvor han selv har været og set gravstenene; men som det fremgår af citatet, befinder det historiske, der optager ham, sig i udkanten af historien og af moderne historieskrivning, som kun inddrager vejrforhold samt afdødes livsomstændigheder, såfremt det har relevans for beskrivelsen eller forklaringen af historiske begivenhedsforløb. Seebergs hensigt med sin litterære historieskrivning er heroverfor at stille skarpt på tilsyneladende uvæsentlige og til tider undselige begivenhedsforløb, der befinder sig i periferien af, hvad der regnes for historisk relevant, hvorved han får dem hævet frem i lyset og givet dem, ikke en verdenshistorisk, men en beskeden, litterær betydning.

Dermed er de pågældende begivenhedsforløb samtidig blevet fiktionaliserede og fremmedgjorte fra en kildekritisk dokumentarisme. En historisk fremstillingsform, som Seebergs fiktionaliserede historier på listeform kan siges at være sammenlig- 
nelig med, er de tidlige, middelalderlige annaler ${ }^{5}$, der fremfor at skildre historiske begivenheder i en fremadskridende, narrativ form opremser dem på en summarisk liste, der er vertikalt opbygget med ingen eller få hændelser for hvert år. Tidsmæssigt er sådanne annaler præget af stor kontinuitet, men på begivenhedsplanet gøres der fra den diskrete, anonyme historieskrivers side intet fors $\varnothing \mathrm{g}$ på at forklare de enkelte hændelser eller på at skabe sammenhæng mellem dem. De fremtræder som enkeltstående nedslag på en tidslinje, der er uden datering - hverken datoen for den enkelte begivenhed eller nedskrivningstidspunktet er anført - og den forekommer at kunne fortsætte i det uendelige eller i det mindste indtil dommedag. Ligesom i Seebergs fiktive dokumentarisme hæfter annalerne sig ofte ved basale livsomstændigheder eller den omgivende natur, for eksempel høstens omfang eller vinterens strenghed, uden at rangere eller fremhæve særskilte begivenheder (White 1980, 11-13).

\section{Hundredårserindringer og noveller med sytten års mellemrum}

I en samtale med Poul Vad, optaget i 1979, kom Seeberg ind på, at han fra og med Dinosaurusens sene eftermiddag havde villet afprøve alle former for overleverede genrer (van der Liet 1998, 99-100). Som vi har set, indebar det tillige en fiktionaliseret genskrivning af udvalgt historisk materiale, primært fra høj- og senmiddelalderen samt fra det 19. og 20. århundrede. Til dette vidtspændende genreprojekt hørte for Seeberg også en idé om at skrive en række noveller, der tidsmæssigt skulle høre sammen ved at foregå med sytten års mellemrum.

Baggrunden for den første af disse noveller, "I middagsstilheden (1859)", der optræder i tekstsamlingen Om fjorten dage fra 1981, er et foto af tre yngre piger fra det 19. århundrede, som Seeberg efter sigende skulle have set på en rejse igennem Tyskland. Det interessante i den sammenhæng er, at fotoet genererer betydning for Seeberg som forfatter, og ikke som historiker, hvilket ville have kastet en anden tilgang og tekst af sig end den fiktive novelle, som blev slutresultatet. Set i sammenhæng med andre tekster i Om fjorten dage forekommer dens overordnede dagsorden at være, som Seeberg selv programmatisk formulerede det, ved hjælp af den præciserende fantasi at erindre sig længere tilbage i tiden, end det egentlig er muligt (Flyvholm 1983).

Således indeholder det første afsnit i Om fjorten dage dels et detaljeret erindringsbillede fra en junidag i 1302, hvor det i højere grad er de toscanske markers naturrigdom, der lægges vægt på, end de historiske samfundsforhold; dels et stykke umulig historieskrivning i form af en fortæller, der gengiver sine erindringer gennem tusind år under opfindelse af fiktive navne, såsom Claus Espensøn Hage og Espen Claussøn Hage, hvoraf førstnævnte bliver slået ihjel, men en navnebroder af ham, hvis mellemnavn ganske vist staves med to 'ss'er', dukker op tre århundreder senere. I erindringspastichen fra Toscana, der i lighed med de emblematiske fortællinger i Renæssancen lægger op til både at skulle ses og høres, er de eneste ord, der udveksles, en kort samtale mellem en rytter og en rejsende på vej til Firenze. Rytterens svar til den rejsende er, at han er to hundrede år for tidligt på den, hvilket han begrunder med, at "Dante er fordrevet, Firenze er ikke sig selv mere" (Seeberg 2017b, 14). Dantes fordrivelse stemmer for så vidt overens med de historiske for- 
hold, men hvilken betydning skal der lægges i rytterens henvisning til, at den rejsende er to hundrede år for tidligt ude?

I det omfang Seeberg har bygget teksten op omkring emblematiske elementer fra Renæssance-tiden, der søger en fortsat fremmedgørelseseffekt ved at kombinere verbale readymades, visuelle elementer og akustiske indslag, så er den lagt anakronistisk an ved at benytte sig af en genreblanding, som hører til to hundreder år senere. Det er ikke kun den rejsende, der er for tidligt på den. Det er den fiktive dokumentarist også. Lignende anakronismer findes i "Erindringer fra tusind år", hvor en munk hævdes at have opfundet vandmøllen d. 7. marts 1119, skønt den ifølge nutidens historiske kilder formodes at have været i brug i Europa tidligere (Seeberg 2017b, 16). Kendskabet til vandmøller blev muligvis først for alvor udbredt i Norden i det 12. århundrede, men de eksisterede allerede, og deres forekomst blev forøget under Valdemar Atterdag, som også nævnes i teksten, dog i en anden forbindelse og lidt tidligere end hans egentlige magtovertagelse i 1340.

Ligesom disse indledende historiske fiktioner skildrer de fleste tekster i Om fjorten dage mennesker, der er ude af takt med den historiske tid enten i den forstand, at de giver indtryk af at høre på en anden tid, eller også giver de selv klart udtryk for ikke at være på højde med den, som historiefortælleren $i$ "Erindringer fra hundrede år": "Det er gået tilbage over hele linjen [...] Tiden er bare gået, og den er ikke gået særligt godt. Objektivt betragtet" (s. 29). Det åbner naturligvis for, at det subjektivt set kunne være gået meget godt, men det lader heller ikke til at være tilfældet. Tværtimod medgiver fortælleren af de hundrede års historie, at han ikke har udrettet noget særligt, og når han lukker øjnene, kan han "ikke komme i tanker om nogetsomhelst. Bly, carbonpapir, gummisko" (s. 30). Det er dog noget, skulle man mene, men målt med det, der har historisk og dermed almen betydning, er det ifølge ham selv "ingenting" andet end private sager eller idiosynkrasier, af hvilke det ikke er alle, som han vil være sig ved.

Den eksistentielle tematik fra Seebergs tidlige forfatterskab, hvis omdrejningspunkt udgjordes af mennesker, der befandt sig på afstand af virkeligheden, indespærret i deres egen oplevelse af tidens tomgang, skinner fortsat igennem i hans senere værker. Det er betydningsfuldt at fremdrage denne problematik for at nå til en dybere forståelse af den måde, hvorpå den seebergske dokumentarisme ind- og omarbejder historisk materiale ved brug af anakronismer og metafiktioner. Den historiske præcisering af datoer og klokkeslæt samt af årstider og vejrforhold forbliver vigtig for Seeberg især med henblik på at fremstille selve tidens gang, der viser sig i glimt, når henholdsvis den fortalte historie og den historiske fortælling går op i limningen. Den historiske tid forløber temmeligt regelret og lader sig "måle" ganske nøjagtigt over generationer og på baggrund af kalendere, dokumenter og klokkeslæt, der ifølge Ricoeur markerer nedslag på en global tidsskala og "integrerer fællesskabet og dets sædvaner i den kosmologiske orden” (Ricoeur 2017, 456). Historien giver mennesket en referenceramme, bogstaveligt talt tidspunkter, at orientere sig efter, hvorved der sker "en genindskrivning af den oplevede tid som privat skæbne eller fælles bestemmelse i den kosmiske tid" (s. 456).

Seebergs fiktive dokumentarisme udfordrer imidlertid den regelrette udmåling af den historiske tid og fremviser de brud, der optræder, når en historiefortæller 
blander de historisk givne kort på nye måder og enten helt undlader at fortælle ved at begrænse sig til at opliste historiske hændelser som i "Genealogi (mandslinje)", eller når et menneske ikke hører hjemme til en bestemt tid og ikke er fuldt integreret i et fællesskab, sådan som det er tilfældet for flertallet af de personer, der optræder i Om fjorten dage. Den historiske tid, der ifølge Ricoeur skulle være "som en bro over den kløft, som adskiller den kosmiske tid fra den oplevede tid" (s. 456), bryder sammen i bestemte øjeblikke i Seebergs prosa og lader de to andre tidsligheder, menneskets egen oplevede tid og tiden på en kosmisk skala, komme mærkbart til syne.

"Drømmen om folket (1875-76)", der følger efter "I middagsstilheden (1859)" i Om fjorten dage, omhandler mindevisesamleren Laust Bøgvad Mikkelsen, som det ikke lykkes at få skrevet Martine Andersdatters viser ned, før hun bliver dræbt af sin egen søn. Dårlig mave, seksuel umodenhed og en uheldig samtale forsinker mindevisesamleren i sit ærinde. Sådanne kontingente forhold, relateret til hovedpersonernes egne eksistentielle problemer, er medvirkende til og bliver ofte udslagsgivende for den historiske overleveringsproces, hvilket også er tilfældet i “Ærinde om formiddagen (maj 1893)": Den unge tjener Christian Schmidt er splittet mellem sin skam over ikke at have fuldbragt sit i øvrigt morbide ærinde, at overdrage en død kat til en garver, og sin længsel efter sin kone, som venter sig. Både mindevisesamleren og tjeneren eksemplificerer bruddet på henholdsvis en overleverings- og en overdragelsesproces, som ikke fuldbyrdes, hvorefter de begge mister orienteringen og ender med at blive kastet tilbage på deres egen skam. De tre piger fra "I middagsstilheden (1859)" oplever lige det modsatte, idet de ublufærdigt gør sig fri af deres families og samtids normer og bliver foreviget nøgne sammen.

Kort efter udgivelsen af Om fjorten dage udtalte Seeberg, at hans intention med værket havde været at "måle tiden" (Seeberg 1983, 120), hvilket ikke lader sig gøre i samme ligefremme forstand som historien. Med hvilket instrument skulle det ske, og hvordan kan en evighed måles? Tekstsamlingen, som modtog Nordisk Råds Litteraturpris for sin behandling af 'det mytiske' begynder og slutter med udblik til evigheden, der kun lader sig 'måle' i kontrast til den historiske tid. I midten af værket fortsætter Seeberg sin kavalkade af noveller med sytten års intervaller, men denne gang med udgangspunkt i ét sted og ét tidspunkt, der fungerer som kalejdoskop for ti parallelfortællinger, som alle udspiller sig i en lille stationsby, ifølge Seeberg med forbillede i Vojens, i november 1927.

Det er muligt, at Seeberg har taget afsæt i historiske dokumenter samt med dertil hørende billedmateriale i sine nærbeskrivelser af mennesker og miljø, men i selve opbygningen af det forestillede historiske stof kommer accenten igen til at ligge på det fiktive. De ti noveller foregår med små tidsforskydninger inden for det samme tidsrum, og deres hovedpersoner forholder sig til hinanden på tværs af alder og erhverv, hvilket er en kunstnerisk tilrettelæggelse af stoffet, som lægger afstand til den historiske dokumentation af handlingsforløb. I lighed med Seebergs to "parallel-romaner", Bipersonerne og Ved havet, bygger stationsby-novellerne på en fortællestruktur uden ét gennemgående handlingsforløb, der i stedet er erstattet af kortere, sideløbende historier, hvori der sjældent sker det store. I Seebergs detailbeskrivelser af det langmodige provinsmiljø skal det store tydeligvis søges i det 
små, som da rengøringsdamen Bothilde gør forberedelser til at sprænge lokummet på stationen i luften med trafikkontrolløren derinde, eller da den tilsyneladende ensomme Ulla Jacobsen pludselig viser nye sider af sig selv og vender op og ned på byens ensidige billede af hende.

Den store historie forbliver for det meste i periferien af de ti fortællinger, men dukker ind imellem op, når eksempelvis bageren i "Mens dejen hæver (nov. 1927)" refererer til Madsen Mygdal, Stauning og skyderier i Berlin, formentlig med reference til voldelige kampe mellem nazister og kommunister (Seeberg 2017b, 124129). Stort set alle de tidstegn, som Seeberg har vævet ind i de ti parallelfortællinger, stemmer overens med historiske sagforhold i 1927, hvilket taler for, at han på den ene side har ønsket at autorisere sin virkelighedsskildring som historisk relevant. På den anden side er selve opbygningen af parallelfortællingerne fiktionaliseret derved, at vægten lægges på, hvad de optrædende personer tænker om verden og hinanden, hvilket overskrider det historisk dokumenterbare. Som Seeberg har for vane, lader han sangen "Dit hjerte er i fare Andresen", fremført i 1936 og også kendt som "Mit hjerte er i fare, Andresen", indgå på anakronistisk vis i et par af fortællingerne (s. 118, 148), der dermed forskydes i retning af det fiktive og fremstår som opdigtede historier, hvis forløb ikke alene udspiller sig parallelt i forhold til hinanden, men også i forhold til historien, sådan som den er blevet overleveret.

Som et afsluttende eksempel på, hvordan Seeberg fiktionaliserer historiske vidnesbyrd skal kortprosateksten "Brev om bly" fra Rejsen til Ribe fremhæves. Blandt denne tekstsamlings noveller, der finder sted med sytten års mellemrum, er den eneste relevante for den nærværende problemstilling "Drengen på forsædet (194445)", som udspiller sig i omegnen af Herning og uden tvivl er skrevet med forlæg i de tyske nazisters likvidering af digterpræsten Kaj Munk. Men ligesom de afsluttende elegier om de romerske regenter, Cæsar og Brutus, der fremstilles som elegikere, lægger de ikke noget afgørende nyt til den allerede fremførte tese om den historiske fortællings sammenbrud i Seebergs fiktive dokumentarisme: de optrædende personer gives et udblik til frelse og måske evighed, som de imidlertid ender med at opgive for i stedet at forsone sig med at være stedt i deres egen oplevelse af tiden som endelig og forgængelig. "Brev om bly" er nyskabende ved at give brevskriveren Laust Gudmundssøn lejlighed til at fremføre sit muntre, men også fantastisk fabulerende verdenssyn, samtidig med at det sår tvivl om pålideligheden af hans egen historiske fremstilling.

Brevet, der er stilet til kong Valdemar Knudssøn, skal være skrevet "på pladsen foran domkirken i Viborg 18. søndag efter Trinitatis A.D. 1247" (Seeberg 2018b, 11). Det stemmer imidlertid ikke overens med de årstal, hvor Valdemar den Store ifølge den historiske overlevering levede og var konge, nemlig i midten af det 12. århundrede. Anvendelsen af så klar en anakronisme i denne sammenhæng er næppe blot ment som et spil for galleriet fra Seebergs side, men kan indføjes som en meningsfuld pointe i læsningen af brevet: Laust Gudmundssøn, som er mester i blytækkerkunst, taler varmt for at indtage en daglig dosis af bly ved at blande det i morgenmælken, da det ifølge ham opmuntrer og giver ekstra kræfter. Han afviser pure, at det skulle have skadelige virkninger eller gøre én grå i ansigtet, hvilket 
læseren næppe skal tage alt for alvorligt, da både han selv og en anden blynyder, bisp Gunnar, er blevet "grå i kinderne" (s. 11). Dertil kommer, at han stiler sin fantastiske fortælling om bly, som han identificerer med "verdens kærne" (s. 11), til en konge, der forlængst er død. Brevskriveren sår uafvidende tvivl om holdbarheden af sin egen hukommelse, som læseren kan have en mistanke om er blevet alvorligt beskadiget af den årelange blyindtagelse.

\section{Konklusion}

Peter Seeberg begyndte først at skrive den form for fiktiv dokumentarisme, som blev et særkende for ham som forfatter, i den midterste periode af sit forfatterskab med udgivelsen af tekstsamlingen Dinosaurusens sene eftermiddag, hvori teksterne "Nekrolog I (Bergske Blade)" og "Genealogi (Mandslinje)" optræder. De er eksempler på hverdagskendte teksttyper, som Seeberg ind- og omarbejder for at afvinde dem en beskeden betydning, der påkalder sig historisk værdi, i og med de foregiver at referere til en historisk virkelighed, samtidig med at de henviser til deres egen fiktive karakter. Begge stykker opretter ligesom det testamente, som også indgår i tekstsamlingen, en spænding mellem det fiktive og det historiske, hvilket inviterer eller måske ligefrem provokerer læseren til at reflektere over pålideligheden af teksten som litterært og historisk dokument.

Seebergs debutroman Bipersonerne kan læses som et stykke fiktionaliseret historie, hvori der indgår elementer fra Seebergs eget ophold i Berlin under anden verdenskrig. Værket foregiver imidlertid ikke selv at være et historisk dokument endsige en historisk roman. Snarere er det en hovedpointe i romanen at skildre afstanden mellem hovedparten af de optrædende bipersoner og den historiske virkelighed ved at stille skarpt på de interne, eksistentielle konflikter, som de gennemlever. I sine senere tekstsamlinger indfælder Seeberg i højere grad sit persongalleri i historien, men han lader vedvarende enkeltpersoner falde ud, særligt i novellerne, der foregår med sytten års mellemrum. Til forskel fra Seebergs rendyrkede fiktive dokumentarisme, som foregiver at præsentere historiske dokumenter, der underløber sig selv som historiske fortællinger, er disse noveller eksempler på en anden form for fiktionaliserede fortællinger, som ikke foregiver at være historiske dokumenter, men nok at have fundet sted på et bestemt historisk tidspunkt, hvilket de dog samtidig sår tvivl om.

Seeberg afprøver i sine tekstsamlinger en lang række genrer fra højmiddelalderen over Renæssancen til moderne tid og anvender ofte anakronismer, der bryder med den regelrette forståelse og opmåling af historisk tid. Han lader sine fortalte historier gå op i limningen, hvorved tiden så at sige skilles ad og udspaltes i to registre, henholdsvis i den nærværende, oplevede tid, som er endelighedens, og den uendeligt udstrakte tid på en kosmologisk skala. Fra sit tidlige til sit sene forfatterskab skildrer Seeberg mennesker, der er nødstedt i deres egen oplevelse af tidens tomgang og skammen over intet at have fuldbyrdet. De oplever hverken at høre til noget fællesskab eller til den historiske tid, som de lever på, og falder i den forstand ud, hvilket Seebergs fortællere imidlertid gengiver med en vis indlevelse, der fremfor at udstille i stedet fremstiller dem i et sympatisk og til tider også komisk lys. Seebergs fiktive 
dokumentarisme, som artiklen har fortolket eksempler på frem til og med Rejsen til Ribe fra 1990, falder vedvarende ud til den fabulerende fantasis side, der konstant underløber den historiske fortællings autoritet.

\section{Noter}

I Seeberg havde selv en mere eller mindre klar ide om, hvor de foregik, men kun i få af teksterne stadfæstes tid og sted nærmere. Jf. samtalen med Hanne Marie Svendsen i Romanens veje. Værkstedssamtaler med danske forfattere (Rasmus Fischers Forlag 1966, 73-89).

2 Seebergs udtalelse om "dobbeltfremmedgørelse" lyder: "formulere indholdet på en måde som ville dobbeltfremmedgøre det hele" (van der Liet 1998, 100).

3 Hvis udtrykket readymade fortsat skal være anvendeligt på Seebergs fiktive dokumentarisme, burde det kaldes for 'verbal readymade', hvilket jeg kort skal vende tilbage til senere.

4 Seeberg har tidligere i sit forfatterskab indsat historisk navnkundige personer, såsom Locke i novellen "Bulen" fra Eftersøgningen, og senere er det Fellini og Bresjnev, der i titelnovellen fra Om fjorten dage befinder sig i en slags limbo.

5 Steen Klitgård Povlsen gør i sit efterskrift til Om fjorten dage opmærksom på, at Seeberg selv antydede, at han i denne og givetvis også i andre tekstsamlinger havde ladet sig inspirere af den annalistiske historieskrivning (Klitgård Povlsen 2017, 263).

\section{Litteratur}

Agrell, Beata (1997): "Documentarism and Theory of Literature", i Poul Houe og Sven Hakon Rossel (red.): Documentarism in Scandinavian Literature, Amsterdam: Rodopi, s. 36-76.

Emerson, Ralph Waldo (1854): The Fugitive Slave Law, https://www.bartleby.com/90/1107.html.

Fabian Lund, Louise (1998): "Skriften er et redningsforsøg", i Weekendavisen Bøger, 17.-23. april 1998

Flyvholm, Flemming (1983): "Vi skal prøve at erindre alt det vi ikke burde kunne erindre", i Audhulma. Nordisk kulturtidsskrift 1, s. 3-6.

Holst Sørensen, Jonas (2003): Peter Seeberg. Estetik, eksistentsfilosofi og kulturanalyse i Peter Seebergs skønlitterære forfatterskab, København: Multivers.

Juhl, Marianne (1989): "Hellere skrive end at plapre", i Berlingske Tidende 25. nov.

Juhl, Marianne (1999): Peter Seeberg. En monografi, København: Gyldendal

Klitgård Povlsen, Steen (2017): “Efterskrift", i Peter Seeberg: Om fjorten dage, København: Gyldendal og Det Danske Sprog- og Litteraturselskab, s. 249-282.

Ricoeur, Paul (2017): "Den fortalte tid", i Peter Kemp (red.): Paul Ricoeur: Danske værker, Kbh: Tiderne Skifter, s. 450-468.

Riisager, Annette (1999): Amor fati - et portæt af Peter Seeberg. Portrætfilm. Sandstrøm, Bjarne (1999): "De seebergske readymades", i Spring 15, s. 50-61.

Seeberg, Peter (1975): "Efterskrift”, i Bipersonerne, København: Gyldendal.

Seeberg, Peter (1983): "En takketale”, i Sprogforeningens almanak for 1983.

Seeberg, Peter (2017a): Dinosaurusens sene eftermiddag, København: Gyldendal og Det Danske 
Seeberg, Peter (2017b): Om fjorten dage, København: Gyldendal og Det Danske Sprog- og Litteraturselskab.

Seeberg, Peter (2018a): Bipersonerne, København: Gyldendal og Det Danske Sprog- og Litteraturselskab.

Seeberg, Peter (2018b): Rejsen til Ribe, København: Gyldendal og Det Danske Sprog- og Litteraturselskab.

Skyum-Nielsen, Erik (2017): "Efterskrift", i Peter Seeberg: Dinosaurusens sene eftermiddag, København: Gyldendal og Det Danske Sprog- og Litteraturselskab, s. 215-251.

Spengler, Oswald (1922): Der Untergang des Abendlandes II, C.H. Beck'sche Verlagsbuchhandlung. van der Liet, Henk (1998): Indfaldsvinkler. En forfattersamtale mellem Peter Seeberg og Poul Vad, København: Gyldendal.

White, Hayden (1980): “The Value of Narrativity in the Representation of Reality", i Critical Inquiry 7.1, s. 5-27.

Åkerlund, Erik (1980): “Tänk att få skriva de nya argumenten”, i Bonniers Litteræra Magasin 1, s. 14-18. 